Evaluating the Impact of Current Sustainability Accounting Practices on ... Heba Shaker Fathy el bably

\title{
Evaluating the Impact of Current Sustainability Accounting Practices on Accounting Reporting- An Empirical Study
}

\author{
Heba Shaker Fathy el bably \\ heba_elbably87@yahoo.com \\ assistant lecturer in accounting department \\ faculty of commerce and business administration - Helwan \\ University.
}

\begin{abstract}
:
Purpose - This paper aims to address and assess the efforts of different international organizations regarding sustainability accounting practices, and how sustainability reporting practitioners face many challenges in preparing sustainability reports and disclosures that affect accounting reporting.

Design/methodology/approach - This study collects and analyzes data from 40 respondents through an online survey. The respondents represent practitioners from various industrial companies in Egypt to see the challenges they face to prepare sustainability reports. Also, to investigate the reporting patterns and standards they follow.
\end{abstract}

Findings - The study found that numerous challenges are affecting the adoption of sustainability accounting, one of which

\begin{tabular}{|c|c|}
\hline العدد الأول الجزء الثاني •.r.r. & المجلد الحادي عشر \\
\hline
\end{tabular}


Evaluating the Impact of Current Sustainability Accounting Practices on ... Heba Shaker Fathy el bably

is the existence of competing frameworks and the absence of a unified framework for sustainability accounting to improve accounting reporting.

Research limitations/implications - As one of the few empirically-based, theoretically informed investigations evaluating the efforts of different organizations in sustainability accounting and the impact of these practices on accounting reporting in literature and application. This study provides insights into evaluating current sustainability accounting practices in Egyptian companies. Its findings, therefore, serve as a foundational basis for further empirical and theoretical inquiry. Originality/value - This study participates in the literature by identifying the significance of the impact of sustainability accounting practices on the quality of accounting reporting by adopting a survey to obtain evidence about the real practice of sustainability accounting in Egypt.

Keywords: Sustainability Accounting, Global Reporting Initiative (GRI), Sustainability Accounting Standards Board (SASB), Practitioners, Egypt.

\section{Introduction:}

Over the last decade, Organizations witnessed a noticeable change in their stakeholder's needs. These changes arise as a consequence of the global financial crisis and the case of economic uncertainty (Adams and Simnett, 2011). Whereas

المجلد الحادي عشر


Evaluating the Impact of Current Sustainability Accounting Practices on ... Heba Shaker Fathy el bably

stakeholders were previously primarily interested in financial statements, attention is growing for other nonfinancial, organizational aspects such as environmental consequences and governance structures (Hertgers, 2016).

Organizations recognized the need to change the way they disclose information in response to its stakeholder's expectations of quality in the product, service, production, and business process. For organizations to meet these demands, they are required to focus on more than just profit maximization. They must take sustainability (economic, social, and environmental) efforts into consideration in reporting about the firm's value and its ability to sustain its operations (Fulop and Hernadi, 2013).

Consequently, the last period witnessed a proliferation of frameworks for non-financial reporting by various professional organizations to satisfy investors' and stakeholders' demands towards the disclosure of sustainability risks and opportunities. This information presented in a variety of formats, including standalone sustainability reports or complementing traditional financial information in corporate annual reports.

The paper is divided into seven sections:

1. Introduction, 2. Current Regulatory and Standard-Setting Environments, 3. General evaluation of the efforts of various organizations, 4. Background about the Global Sustainability

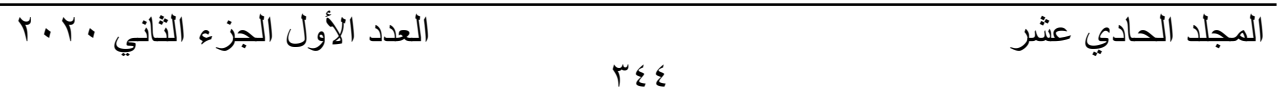


Evaluating the Impact of Current Sustainability Accounting Practices on ... Heba Shaker Fathy el bably

Standards Board (GSSB) and Sustainability Accounting Standards Board (SASB) standards, 5. General Evaluation of SASB and GSSB efforts, 6. Empirical Study, 7. Conclusion.

\section{Current Regulatory and Standard-Setting Environments:}

Concerning the regulatory environment, it is necessary to distinguish between regulations restricting firms' operating activities and regulations requiring firms to report on their actions related to sustainability (Hales et al., 2016). While there is a previous long history, the domestic and global regulatory environment for sustainability reporting is still reasonably growing.

In the past twenty-five years, the world has seen exponential growth in the number of companies measuring and reporting environmental (such as carbon emissions, water consumption, waste generation), social (such as employee, product, customerrelated), and governance (such as political lobbying, anticorruption, board diversity) data, collectively ESG data. While fewer than 20 companies disclosed ESG data in the early 1990s, the number of companies issuing sustainability or integrated reports had increased to nearly 9,000 by 2016 (Amel-Zadeh \& Serafeim, 2017).

In fact, in 1997, Finland became one of the first countries to enact a mandatory sustainability reporting law. Most

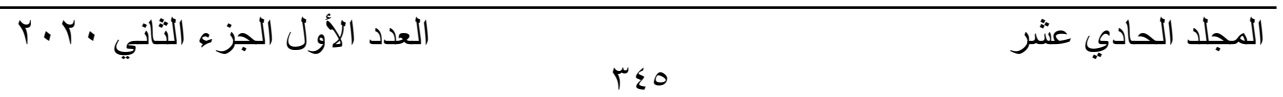


Evaluating the Impact of Current Sustainability Accounting Practices on ... Heba Shaker Fathy el bably

sustainability reporting remains voluntary and unaudited, although assurance rates among the largest firms have recently moved above 50 percent. While country-level practices have varied dramatically, significant changes are forthcoming. In 2014, the European Commission passed a requirement for all large public companies to begin reporting annually on specific ESG information by 2017, although it left companies with significant latitude in determining what information would be most useful. European companies will, therefore, must either develop their reporting models or look to standard setters for guidance (Hales et al., 2016) or (Hales, Matsumura, Moser, \& Payne, 2016)

In response to that, a study carried out by Ernst and Young in 2014 reported that $95 \%$ of the largest 250 business entities in the world prepare sustainability reports. As a result, the number of standards, guidelines, and frameworks increases due to rising interest in incorporating sustainability (E\&Y, 2014).

While the growth in interest is positive, the proliferation of governmental, private, NGO, and other frameworks have resulted in an international reporting landscape that is increasingly complex. There is also increasing evidence that regulators (governments and stock exchanges) are looking to mandatory reporting requirements to address heightened public and

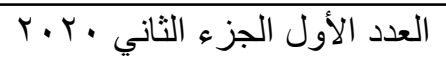

المجلد الحادي عشر 

2014).

Hence, the researcher will display through the following table a summary of some of these standards and frameworks.

Table (1)

\section{Summary of some of the organizations and initiatives involved in sustainability standards setting (Deloitte, 2016; other websites)}

\begin{tabular}{|c|c|c|c|c|}
\hline \begin{tabular}{|l|} 
Company/ \\
organization
\end{tabular} & \begin{tabular}{|l|} 
Symbol and \\
Year $\quad$ of \\
foundation
\end{tabular} & Description & Form of report & Main Audiences \\
\hline \begin{tabular}{|l|} 
World \\
Business \\
Council for \\
Sustainable \\
development
\end{tabular} & $\begin{array}{l}\text { WBCSD } \\
(1995)\end{array}$ & $\begin{array}{l}\text { It is a global association formed } \\
\text { from } 200 \text { companies. It provides } \\
\text { entities with principles to } \\
\text { explore sustainable } \\
\text { development. }\end{array}$ & $\begin{array}{l}\text { It works on a } \\
\text { variety of issues } \\
\text { related to } \\
\text { sustainable } \\
\text { development to } \\
\text { achieve } \\
\text { the } \underline{\text { Sustainable }} \\
\text { Development } \\
\text { Goals (SDGs). }\end{array}$ & $\begin{array}{l}\text { One of the most } \\
\text { substantial } \\
\text { forums for } \\
\text { businesses on } \\
\text { corporate social } \\
\text { responsibility } \\
\text { (CSR) issues. }\end{array}$ \\
\hline $\begin{array}{l}\text { AccountAbility } \\
\text { Institute }\end{array}$ & \begin{tabular}{|l} 
AAI \\
$(\mathbf{1 9 9 5 )}$
\end{tabular} & $\begin{array}{l}\text { It is an international professional } \\
\text { institute that focuses on } \\
\text { sustainable development, } \\
\text { accountability, and public } \\
\text { disclosure. } \\
\text { It aims to "develop new tools, } \\
\text { thinking, and connections that } \\
\text { enable individuals, institutions } \\
\text { and alliances to respond better to } \\
\text { global challenges." } \\
\text { Provide business, government } \\
\text { agencies, and multilateral } \\
\text { organizations with relevant, } \\
\text { insightful, and useful research } \\
\text { papers, reports, and literature. }\end{array}$ & \begin{tabular}{|l|} 
It is not \\
specified. \\
It gathers \\
information to \\
provide users \\
with a better \\
quality of service \\
to keep internal \\
records and \\
process \\
improvements.
\end{tabular} & \begin{tabular}{|l} 
AccountAbility \\
Institute \\
provides \\
information to a \\
broad spectrum \\
of organizations \\
like global \\
businesses, \\
private \\
enterprises, \\
governments, \\
and civil \\
societies.
\end{tabular} \\
\hline
\end{tabular}

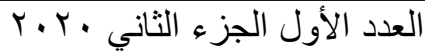


Heba Shaker Fathy el bably

\begin{tabular}{|c|c|c|c|c|}
\hline $\begin{array}{l}\text { Global } \\
\text { Reporting } \\
\text { Initiative }\end{array}$ & $\begin{array}{l}\text { GRI } \\
\text { (1997) }\end{array}$ & $\begin{array}{l}\text { Provides reporting guidelines to } \\
\text { enable different stakeholders to } \\
\text { make sustainable decisions. GRI } \\
\text { is the most adopted framework } \\
\text { for sustainability reporting. }\end{array}$ & $\begin{array}{l}\text { Sustainability } \\
\text { report }\end{array}$ & $\begin{array}{l}\text { A broad set of } \\
\text { stakeholders }\end{array}$ \\
\hline $\begin{array}{l}\text { Dow Jones } \\
\text { Sustainability } \\
\text { Index }\end{array}$ & $\begin{array}{l}\text { DJSI } \\
\text { (1999) }\end{array}$ & $\begin{array}{l}\text { A group of indices launched in } \\
1999 \text { as the first } \\
\text { global sustainability benchmark } \\
\text { s to evaluate the sustainability } \\
\text { performance of the largest } 2,500 \\
\text { S\&P firms. }\end{array}$ & $\begin{array}{l}\text { Robeco SAM } \\
\text { questionnaire }\end{array}$ & Investors \\
\hline $\begin{array}{l}\text { United Nations } \\
\text { Global } \\
\text { Compact }\end{array}$ & $\begin{array}{l}\text { UN Global } \\
\text { Compact } \\
(2000)\end{array}$ & $\begin{array}{l}\text { It motivates businesses all over } \\
\text { the world to adopt sustainable, } \\
\text { responsible policies and to } \\
\text { report on their implementation } \\
\text { procedures to achieve its ten } \\
\text { principles. } \\
\text { It concentrates on the areas of } \\
\text { human rights, labor, } \\
\text { environment, and anti- } \\
\text { corruption. } \\
\text { It is the world's largest corporate } \\
\text { sustainability initiative, with } \\
13000 \text { corporate participants and } \\
\text { other stakeholders over } 170 \\
\text { countries. }\end{array}$ & $\begin{array}{l}\text { Sustainability } \\
\text { report }\end{array}$ & Different Parties \\
\hline $\begin{array}{l}\text { Carbon } \\
\text { Disclosure } \\
\text { Project }\end{array}$ & $\begin{array}{l}\text { CDP } \\
(2000)\end{array}$ & $\begin{array}{l}\text { Provide investors and cities with } \\
\text { information about climate } \\
\text { change, water, and carbon data } \\
\text { to be able to mitigate risk, } \\
\text { exploit opportunities, and make } \\
\text { investment decisions that } \\
\text { support the accomplishment of a } \\
\text { more sustainable world. }\end{array}$ & $\begin{array}{l}\text { CDP } \\
\text { questionnaire }\end{array}$ & \begin{tabular}{|ll} 
Investors and \\
other \\
stakeholders
\end{tabular} \\
\hline $\begin{array}{l}\text { The Prince's } \\
\text { Accounting for } \\
\text { Sustainability } \\
\text { Project }\end{array}$ & $\begin{array}{l}\text { A4S } \\
(2004)\end{array}$ & $\begin{array}{l}\text { A4S was set up by HRH The } \\
\text { Prince of Wales to help ensure } \\
\text { that the best of 20th-century } \\
\text { decision making and reporting } \\
\text { systems are undertaken to meet } \\
21 \text { st-century challenges. } \\
\text { A4S has many objectives; the } \\
\text { most significant one is } \\
\text { transforming the decision- }\end{array}$ & Not specified & $\begin{array}{l}\text { Companies, } \\
\text { investors and } \\
\text { governments }\end{array}$ \\
\hline
\end{tabular}

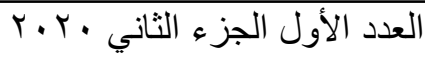

المجلد الحادي عشر 
Heba Shaker Fathy el bably

\begin{tabular}{|c|c|c|c|c|}
\hline & & $\begin{array}{l}\text { making process from } \\
\text { considering only the economic } \\
\text { dimension into taking the } \\
\text { opportunities and risks posed by } \\
\text { environmental and social issues } \\
\text { into consideration. }\end{array}$ & & \\
\hline \begin{tabular}{|l|} 
International \\
Organization \\
for \\
Standardization \\
ISO
\end{tabular} & $\begin{array}{l}\text { ISO } 26000 \\
\text { (Guidance } \\
\text { on } \quad \text { Social } \\
\text { responsibilit } \\
\text { y) } \\
\text { ISO } 14000 \\
\text { (Environme } \\
\text { ntal } \\
\text { managemen } \\
\text { t) } \\
\text { ISO 31000 } \\
\text { (Risk } \\
\text { managemen } \\
\text { t) } \\
\text { (2010) }\end{array}$ & $\begin{array}{l}\text { ISO } 26000 \text { guides organizations } \\
\text { on how to behave in a socially } \\
\text { responsible way. It helps } \\
\text { organizations to put principles } \\
\text { into actions and shares best } \\
\text { practices. } \\
\text { ISO } 14000 \text { presents practical } \\
\text { means for companies and } \\
\text { organizations of all kinds, } \\
\text { looking to manage their } \\
\text { environmental responsibilities. } \\
\text { ISO } 31000 \text { guides organizations } \\
\text { to improve the identification of } \\
\text { opportunities and threats and } \\
\text { effectively allocate and use } \\
\text { resources for risk treatment, } \\
\text { management, and corporate } \\
\text { governance. }\end{array}$ & Not Specified & $\begin{array}{l}\text { Any entity, } \\
\text { regardless of its } \\
\text { size, activity, or } \\
\text { sector. }\end{array}$ \\
\hline \begin{tabular}{|l|} 
International \\
Integrated \\
Reporting \\
Council
\end{tabular} & $\begin{array}{l}\text { IIRC } \\
(2010)\end{array}$ & $\begin{array}{l}\text { The IIRC was created to } \\
\text { establish integrated reporting } \\
\text { and thinking within the } \\
\text { mainstream business practice for } \\
\text { both the public and private } \\
\text { sectors. }\end{array}$ & $\begin{array}{l}\text { Integrated } \\
\text { annual report or } \\
\text { standalone report }\end{array}$ & $\begin{array}{l}\text { Providers of } \\
\text { financial capital }\end{array}$ \\
\hline $\begin{array}{l}\text { Sustainability } \\
\text { accounting } \\
\text { standards board }\end{array}$ & $\begin{array}{l}\text { SASB } \\
(2012)\end{array}$ & $\begin{array}{l}\text { SASB established to construct } \\
\text { and improve industry-specific } \\
\text { metrics. These metrics help } \\
\text { investors in the US into } \\
\text { investment decisions through } \\
\text { standardizing sustainability } \\
\text { disclosure and effective ESG } \\
\text { integration. }\end{array}$ & $\begin{array}{l}\text { SEC } 10-\mathrm{K} \text {, } \\
20-\mathrm{F} \text { filings }\end{array}$ & $\begin{array}{l}\text { Investors in US } \\
\text { public } \\
\text { companies }\end{array}$ \\
\hline
\end{tabular}

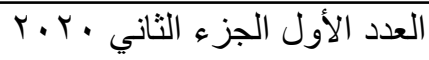


Evaluating the Impact of Current Sustainability Accounting Practices on ...

Heba Shaker Fathy el bably

3. General Evaluation of the efforts of various organizations:

From the previous display of the different organization's efforts regarding sustainability, the researcher concluded the following:

3.1Several global reporting frameworks exist to help entities in measuring and reporting sustainability information to a broad range of stakeholders, from employees, customers, and investors to suppliers, regulators, and civil society organizations.

3.2The Existing sustainability standard-setting and reporting initiatives are developed to help business entities determine how to communicate their sustainability performance. Companies can manage their risks more effectively in an increasingly resource-constrained world and gain a competitive advantage by creating a reliable sustainability reporting and disclosure plan using a robustdeveloped framework to achieve ESG transparency.

3.3The current financial and accounting systems focus on short term financial outcomes and do not adequately reflect the dependency of economic success on the health and stability of societies and the natural environment.

3.4The requirements and contents of these reports vary widely and are dissimilar in identifying sustainability dimensions

r.r. العدد الأول الجزء الثاني

ro.

المجلد الحادي عشر 
Evaluating the Impact of Current Sustainability Accounting Practices on ... Heba Shaker Fathy el bably

and contextual information, which makes comparisons among organizations' sustainability goals difficult. This inconsistency may derive from organizations' focus on divergent interests, which stem from their different institutional affiliations. For example, some companies emphasize people and others underscore environmental impact on their sustainability reporting. Moreover, some reports focus primarily on the customers, while others focus on employees (Nielsen \& Thomsen, 2007). These differences in Sustainability report content can also occur because organizations have different corporate-specific strategies and continue to evolve their related sustainability initiatives and refine their sustainability-related messages consistent with those strategies (Bradford, Earp, Showalter, \& Williams, 2017).

3.5Lack of a unified sustainability reporting and assurance might reduce the comparability, effectiveness, and accuracy of sustainability accounting reporting (Guo and Yang, 2014).

3.6The existing reporting frameworks can be either commonly used standards or disclosure guidelines that companies, public entities, governments, and other organizations follow to present significant environmental information and raise awareness on the reporting of carbon and climate risk. Although there are private standards, 
Evaluating the Impact of Current Sustainability Accounting Practices on ... Heba Shaker Fathy el bably

accounting standards, and frameworks for harmonization, the information disclosed varies substantially in terms of their relevance, quality, quantity, and timeliness, which can lead to substantial confusion to reporters (E\&Y, 2014).

3.7Some of these initiatives are principles-based Standards, and frameworks such as AccountAbility and GRI, and others are rules-based or have a more practical application emphasis such as (SASB). Hence, the researcher will address and evaluate both GSSB and SASB standards in more detail in the following sections, as they are the most common frameworks in sustainability accounting.

\section{Background about the Global Sustainability Standards Board (GSSB) and Sustainability Accounting Standards Board (SASB) standards:}

\subsection{Global Sustainability Standards Board (GSSB):}

The most widely existing and used guidelines for sustainability accounting reporting is the Global reporting initiative (GRI) (KPMG, 2013). It was initiated by the Coalition for Environmentally Responsible Economics (CERES) and the UN Environment Program in 1997 as a nonprofit organization comprising businesses, government, social advocacy, and other stakeholders, maintains a "Sustainability Disclosure Database,', which provides access to an affluence of sustainability

العدد الأول الجزء الثاني •r.r.

المجلد الحادي عشر 
Evaluating the Impact of Current Sustainability Accounting Practices on ...

Heba Shaker Fathy el bably

information voluntarily reported by companies (GRI 2014a; Bradford, Earp, Showalter, \& Williams, 2017). In 2002, the GRI became an independent body to guide international public and private entities that wish to produce sustainability reports (GRI 2014b; Bradford, Earp, Showalter, \& Williams, 2017; Hales et al., 2016; (Hales, Matsumura, Moser, \& Payne, 2016).

GRI's reporting objective for entities following its standards is to produce a report that 'reflects the organization's economic, environmental and social impacts", and should include all material information, where materiality is defined as information that could "substantively influence the assessments and decisions of stakeholders" (GRI 2013, 17). GRI guidelines have been developed to meet the needs of a broad range of stakeholders. The scope of issues covered in the guidelines includes economic, environmental, social, and governance topics. The GRI proposes reporting on nearly 80 "sustainability indicators" classified into six different dimensions. These dimensions are labor and decent work, economics, environment, human rights, society, and product responsibility (GRI 2014b; Bradford et al., 2016; Hales et al., 2016). Although companies may not need to report about all sustainability indicators on their sustainability reports, they are eligible to register with the GRI (Bradford et al., 2017).

العدد الأول الجزء الثاني •r.r. 
Evaluating the Impact of Current Sustainability Accounting Practices on ... Heba Shaker Fathy el bably

Therefore, entities that follow GRI are producing two necessary reports: an annual report of their financial operations according to financial accounting standards established either by the International Accounting Standards Board (IASB) Financial or Accounting Standards Board (FASB) and a sustainability report prepared by GRI guidelines (Hales et al., 2016).

In November 2015, a transition to standards was initiated by the GRI's independent standard-setting body, Global Sustainability Standards Board (GSSB). The principal intention of this change is to restructure the content of the G4 Guidelines and Implementation Manual to a set of modular, interrelated GRI Sustainability Reporting Standards (GRI Standards). The transition from G4 to GRI Standards mostly concentrates on improving the structure and format of the G4 content. The GRI Standards will be more simple to keep up-to-date and more suitable for referencing in policy initiatives around the world (GSSB, 2016). As a result, GRI launched its first global standards for sustainability reporting in October 2016 that mainly are based on the previous GRI G4 Guidelines (Haskin \& Burke, 2016).

The new GRI Standards begin with three Universal Standards to disclose general information about an organization and its approaches to sustainability management. Further topic-specific standards outline approaches to disclosing qualitative and

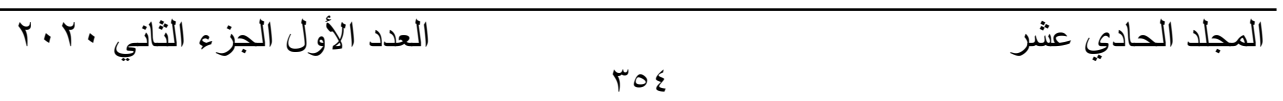


Evaluating the Impact of Current Sustainability Accounting Practices on ... Heba Shaker Fathy el bably

quantitative information deemed material to each reporting organization (GRI 101 Foundation, 2016).

Briefly, the new set of standards are classified into the following:

1- GRI 101 Foundation: The starting point for using the GRI Standards.

2- GRI 102 General Disclosures: Used to report contextual information about the organization.

3- GRI 103 Management Approach: Used to disclose how the organization manages impacts related to each of its material topics.

4- Topic-specific standards: Classified into three series (200 Series Economical, 300 Series Environmental, 400 Series Social).

\subsection{Sustainability accounting standards board (SASB):}

Sustainability Accounting Standards Board (SASB) is founded in 2011 as an independent nonprofit organization to develop sustainability accounting standards. SASB standards focus mainly on financial material issues to help companies around the world report on sustainability topics, including (environmental, social, and governance topics) that matter most to investors. To

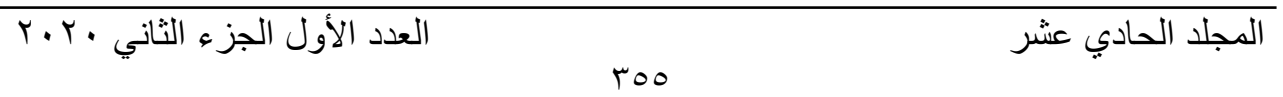


Evaluating the Impact of Current Sustainability Accounting Practices on ...

Heba Shaker Fathy el bably

realize its goal, in November 2018, SASB developed a complete set of 77 industry-specific standards to identify the minimum set of financial material sustainability topics and their associated metrics for the regular company in an industry. SASB followed a Conceptual Framework and Rules of Procedure to develop these standards. These standards are designed for voluntary use to fulfill the requirements of U.S. regulation in filings such as Forms $10-\mathrm{K}$ and $20-\mathrm{F}$ with the Securities and Exchange Commission (SEC) disclosures. The SASB's due process principle mission is to provide standards to present information that is first, expected to be material; second, decision-useful for companies and their investors; and third, cost-effective for corporate issuers (SASB Conceptual framework, 2017).

SASB's objective partially combines the objectives of GRI and the IIRC. Like the IIRC, SASB's model is one of integrated reporting. In particular, SASB aims to aid U.S. public companies in meeting the requirement of Item 303 of Regulation S-K to disclose material information in the management discussion and analysis section of their $10-\mathrm{K}$ and $20-\mathrm{F}$ filings regarding known trends and uncertainties that could affect a registrant's operations.

SASB is developing industry-specific sustainability accounting standards to fulfill the material information disclosure requirements of the Securities and Exchange Commission (SEC)

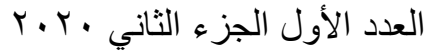

المجلد الحادي عشر - المر 
Evaluating the Impact of Current Sustainability Accounting Practices on ... Heba Shaker Fathy el bably

(E\&Y, 2014). Each standard is divided into three main parts; accounting metrics for each industry-specific disclosure topic, the technical protocol for compiling data, and activity metrics for normalization.

\section{General Evaluation of SASB and GSSB efforts:}

Although there is no clear link between GRI and SASB, GRI has a significant influence on the founders of SASB. GRI advocates the viewpoint that a sustainable global economy "should combine long-term profitability with ethical, social justice and environmental care" (GRI, 2013).

GRI suggests a comprehensive sustainability agenda rather than focus on investor decision making. Its standards are designed for companies to voluntarily report to a broad range of stakeholders - employees, interest groups, policymakers, suppliers, customers, communities, and others, in addition to investors while SASB's principal focus is on investors' interests and reporting of material sustainability-related information in SEC filings.

Implementation of the GRI G4 Guidelines "Principles for Defining Report Content', (precisely Materiality Principle) will result in more diversity in practice, thereby further complicating the comparability concern. Additionally, the GRI has initiated

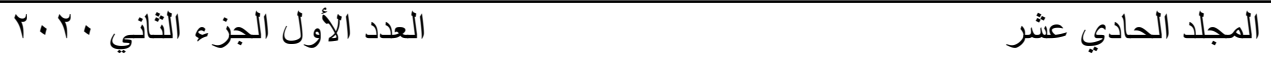


Evaluating the Impact of Current Sustainability Accounting Practices on ...

Heba Shaker Fathy el bably

efforts to become a more established international standard-setter for sustainability reporting (GRI 2015a; 2015b).

While the GRI standards are directed to the global public, SASB focuses on U.S. companies and industries through developing its own Sustainability Industry Classification System. Instead of classifying firms by revenue source, SASB ranks companies by sustainability attributes, including risks and opportunities.

SASB aims to provide standardized accounting metrics for industry-level material sustainability issues, unlike GRI, which has less of an industry focus. Additionally, whereas GRI's materiality threshold is set around stakeholder decision making, SASB is focused on equity and debt investors, and so follows U.S. securities law, which defines materiality as information that could be viewed by the reasonable investor as having altered the total mix of information made available significantly (SASB, 2013). SASB, therefore, provides what is arguably the most restrictive definition of materiality, potentially minimizing the set of nonfinancial information to be disclosed (Hales et al., 2016).

From the previous, the researcher sees that numerous challenges are preventing the adoption of sustainability reporting, and these challenges are somewhat interrelated as follows:

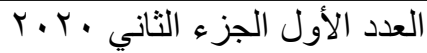

المجلد الحادي عشر 
Evaluating the Impact of Current Sustainability Accounting Practices on ... Heba Shaker Fathy el bably

\subsection{Existence of Competing frameworks:}

The existence of competing frameworks and standards designed for different audiences create difficulties for companies and investors; for example, the GRI reporting framework focuses on stakeholders, whereas SASB focuses on investors.

The most widely spread applicable framework is the GRI framework; however, companies that apply it also face another issue as they lack consistency in following its different versions of guidelines (e.g., G3, G3.1, or G4). Moreover, some companies may apply an internally developed methodology rather than GRI standards (PricewaterhouseCoopers, 2017). On the other hand, SASB standards are more acceptable to U.S. corporations and SEC filings.

Correspondingly, there is a critical need for a unified framework and standards for all business entities all over the world to follow to achieve greater consistency and comparability across reporting entities.

\subsection{Lack of a specific standard measure:}

Sustainability information faces measurement uncertainty issue due to different measurement methods, or the incompleteness of the data, and other factors (Munoz, Zhao, \& Yang, 2017). Either on GRI Standards or SASB industry-specific standards, there is a lack of a standardized unit of measure for the same performance

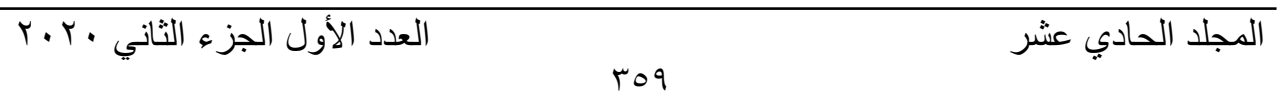


Evaluating the Impact of Current Sustainability Accounting Practices on ... Heba Shaker Fathy el bably

indicator across ESG topic areas. For example, the various measures of energy consumption around the world, such as (gigajoules, kilowatt-hours). Also, some companies refer to their social efforts in terms of the number of training hours, injury rates, and many other factors). As a result, the lack of a standard unit for reporting leads to difficulties in both creating information of value and using this information to make decisions.

\subsection{Compliance and Enforcement:}

As sustainability reporting is voluntary, there are no legal obligations on companies for noncompliance. Additionally, companies that prepare a sustainability report do not face penalties for errors as there is no standardized approach to corrective action. On the contrary, misstatements occurrence is less likely to happen as the company is the one who assesses the negative impacts as significant to report about the responsibility of its occurrence and how it can manage it (Hahn \& Lülfs, 2013). The lack of the assurance requirement for sustainability reporting by a third party represents another issue for non-compliance, which may lead to fraudulent acts and, therefore, distorted information.

\subsection{Definitions:}

GRI defined "Sustainability reporting" as an organization's practice of reporting publicly on its economic, environmental,

العدد الأول الجزء الثاني •r.r. 
Evaluating the Impact of Current Sustainability Accounting Practices on ... Heba Shaker Fathy el bably

and social impacts, and hence its contributions - positive or negative - towards the goal of sustainable development (GRI 101 Foundation, 2016). The researcher sees that the primary emphasis of GRI is on the impacts of the organizational activities on the external environment, ignoring the effect of these impacts on the organization itself and its ability to sustain in its operations. On the other side, SASB defined sustainability as corporate activities that support or improve the company's ability to create value and sustain over the long term. SASB defines Sustainability accounting as the measurement, management, and reporting of such corporate activities. (SASB Conceptual Framework, 2017).

The researcher sees that there is a conflict between definitions of sustainability accounting and reporting from GRI and SASB perspectives, which lead to inconsistent measurements. Both are designed for different but complementary purposes. Whereas GRI looks at the company's impacts on the world, and the SASB looks at the world's impacts on the company.

\subsection{Standardization}

Companies lack comparability and homogeneity due to the presence of different sustainability reporting guidelines and standards with different approaches. Additionally, the standards

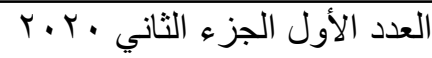
المجلد الحادي عشر 
Evaluating the Impact of Current Sustainability Accounting Practices on ... Heba Shaker Fathy el bably

and indices should focus not only on the overall sustainability performance but also on stratifying performance by industry. The one size fits all approach to sustainability reporting is not conducive to a diverse economy (Sidhar, 2013). In terms of disclosure, there are discernible trends for each industry. Disclosures have a strategic focus and competitive landscapes within which different industries operate as well as the presence of industry-specific success factors such as the heavy dependence on human resources or individual-specific intellectual capital (Cohen, Holder-Webb, Nath \& Wood, 2012; Munoz et al., 2017).

The researcher sees that the selective disclosure stated in GRI standards sustainability presents a potential bias.

This issue can be treated through regulators who should work on mandating some of these disclosures and standardizing certain aspects of disclosures to prevent companies from hiding negative or bad news and disclosing positive or good news (Coram, Monroe \& Woodliff, 2009; Munoz, 2017).

\subsection{Differences in materiality definitions:}

GRI views materiality as the report shall cover topics that reflect the reporting organization's significant economic, environmental, and social impacts; or substantively affect the assessments and decisions of stakeholders.

العدد الأول الجزء الثاني •.r.

المجلد الحادي عشر 
Evaluating the Impact of Current Sustainability Accounting Practices on ...

SASB standards defined materiality according to the U.S. Supreme Court, information is material if there is "a substantial likelihood that the reasonable investor would have viewed the disclosure of the omitted fact as having altered the 'total mix' of information made available significantly."

SASB concentrates on the disclosure of sustainability topics that affects the financial condition or operating performance of companies in each industry. SASB provides each company the right to decide what information is material and the one they will disclose in its SEC filings. SASB depends on the definition of "materiality" established under the U.S. securities laws in identifying sustainability issues that have material impacts.

The concept of materiality in both boards needs more clearance and more restrictions as it may allow organizations to bias for primarily focus on disclosing favorable information, and therefore manipulation.

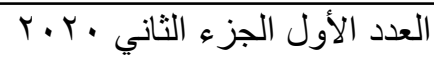
المجلد الحادي عشر 
Evaluating the Impact of Current Sustainability Accounting Practices on ... Heba Shaker Fathy el bably

\section{Table (2)}

\section{Summary of the main differences between GSSB and SASB}

\begin{tabular}{|l|l|l|}
\hline & \multicolumn{1}{|c|}{ GSSB } & \multicolumn{1}{c|}{ SASB } \\
\hline Type of guidance & GRI G4 Guidance & SASB Standards \\
\hline Scale & International & U.S. \\
\hline Scope & General & Industry-Specific \\
\hline Target disclosure & Voluntary filing & Mandatory SEC fillings \\
\hline Target reporters & $\begin{array}{l}\text { Public and private } \\
\text { companies }\end{array}$ & $\begin{array}{l}\text { Public companies traded on } \\
\text { U.S.exchanges }\end{array}$ \\
\hline Target audience & All stakeholders & Investors \\
\hline
\end{tabular}

\section{Sustainability accounting in practice (Empirical study in Egypt):}

According to the pilot study titled "The Impact of Current Sustainability Accounting Practices on accounting Reporting Quality," the researcher selected a sample of fifty practitioners working for companies from various sectors in Egypt for the year 2019. The main target from the empirical study is to find out how far Egyptian companies are preparing sustainability reports, identify the main challenges they face to prepare these reports, and 
Evaluating the Impact of Current Sustainability Accounting Practices on ... Heba Shaker Fathy el bably

investigate the reporting patterns and standards they follow.

Charts from (1) to (4) show the extent to which the sample companies account for sustainability activities and prepare sustainability reports affiliated with financial reports, reasons for non-issuance of the sustainability report, challenges that face companies to prepare sustainability reports,

\subsection{Issuance of Sustainability Report:}

Chart (1) shows that $52 \%$ of the respondent companies are issuing sustainability reports, while $48 \%$ are not issuing this type of report. Concerning the companies that do not issue sustainability reports, the researcher argues that nonissuance of sustainability reports maybe because of the imperfect knowledge of the practitioners about sustainability reporting, or the limitation of the Arabic literature to identify the steps to be followed to prepare this type of reports, also the missing link between practitioners and academics may be one of the reasons of the nonapplication, and also the poor knowledge of the practitioners regarding the significance of sustainability

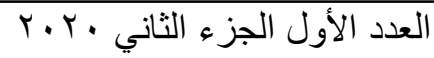

المجلد الحادي عشر 
Evaluating the Impact of Current Sustainability Accounting Practices on ... Heba Shaker Fathy el bably

reporting shed the light of the main reason behind notreporting, which is the fear of change.

\section{Chart (1)}

\section{Issuing a sustainability report in Egypt}

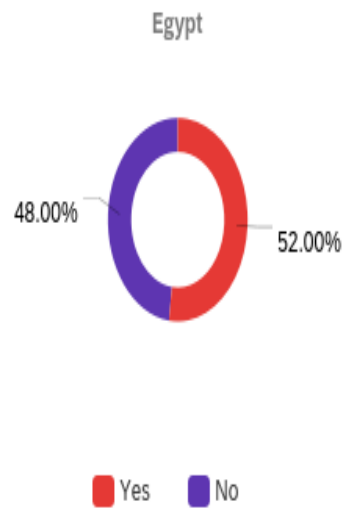

\subsection{Reasons for non-issuance of sustainability report:}

Chart (2) shows the perspectives of the practitioners who stated that their companies are not issuing a sustainability report regarding the reasons for not issuing on a scale ranked from one to five, where one represents stronglydisagree (1) and five strongly-agree (5).

From the literature, the researcher mentioned that the nonissuance of sustainability reports might be embedded behind some principal reasons as no one is asking for this

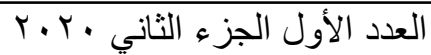

المجلد الحادي عشر 
Evaluating the Impact of Current Sustainability Accounting Practices on ... Heba Shaker Fathy el bably

information, or maybe the company intends to do so but do not have the resources to prepare a public report, or the company tracks this information internally but elect not to publish it or any other reasons. The results indicate that accountants that choose "No one is asking for this information" as the main reason for not issuing sustainability reports represent the highest average (mean $=3.95$ ) while the choice of "We intend to do so but do not have the resources to prepare a public report" has the lowest average responses (mean $=2.77$ ). Accountants' responses regarding the second choice had a standard deviation of " 1.38 " whereas the responses regarding the fourth choice had a standard deviation of " 1.05 ". The second choice had the highest standard deviation, which reflects that the opinions regarding the second reason are more spread out or dispersed than other choices.

r.r. العدد الأول الجزء الثاني المجلد الحادي عشر 
Evaluating the Impact of Current Sustainability Accounting Practices on ...

Heba Shaker Fathy el bably

\title{
Chart (1-2)
}

\section{Reasons for not preparing the sustainability report}

\author{
Egypt
}

We intend to do so but do not have the

No one is asking for this information.

resources to prepare a public report.
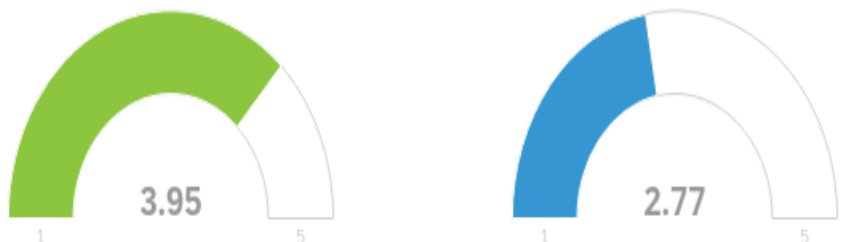

We track this information internally but elect not to publish it.

Other reasons. Please specify
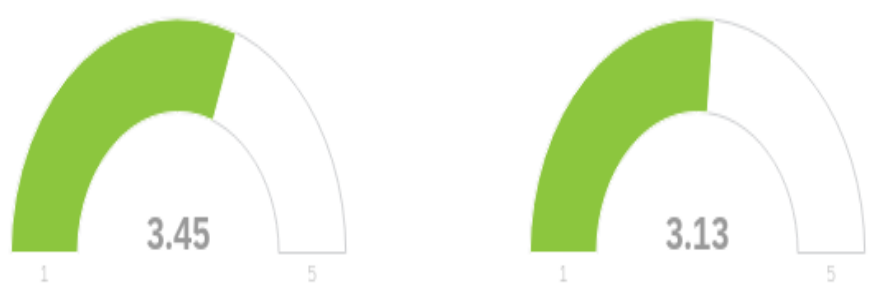

العدد الأول الجزء الثاني · ب .

المجلد الحادي عشر 
Evaluating the Impact of Current Sustainability Accounting Practices on ... Heba Shaker Fathy el bably

\begin{tabular}{|c|c|c|c|c|c|}
\hline \multicolumn{6}{|c|}{ Table (3) } \\
\hline \# & Field & Mean & $\begin{array}{c}\text { Std } \\
\text { Deviation }\end{array}$ & Variance & Count \\
\hline 1 & $\begin{array}{l}\text { No one is asking } \\
\text { for this information. }\end{array}$ & 3.95 & 1.19 & 1.41 & 22 \\
\hline 2 & $\begin{array}{l}\text { We intend to do so } \\
\text { but do not have the } \\
\text { resources to prepare } \\
\text { a public report. }\end{array}$ & 2.77 & 1.38 & 1.90 & 22 \\
\hline 3 & $\begin{array}{l}\text { We track this } \\
\text { information } \\
\text { internally but elect } \\
\text { not to publish it. }\end{array}$ & 3.45 & 1.12 & 1.25 & 22 \\
\hline 4 & $\begin{array}{l}\text { Other reasons. } \\
\text { Please specify }\end{array}$ & 3.13 & 1.05 & 1.11 & 8 \\
\hline
\end{tabular}

\subsection{Challenges that face companies to prepare sustainability reports:}

Chart (3) shows the challenges or the issues that companies face to prepare sustainability reports, according to the pilot study the researcher found that $50 \%$ of the practitioners stated that "Limited resources" represent the primary issue that prevents them from issuing sustainability reports. The remaining $50 \%$ of the responses are divided into $25 \%$, see "Inaccuracy of data" hinder them from reporting while $16.67 \%$ of the responses considered "Incomplete data" the primary issue, and 8.33\% specified other reasons other than those mentioned.

r.r. العدد الأول الجزء الثاني

المجلد الحادي عشر 
Evaluating the Impact of Current Sustainability Accounting Practices on ... Heba Shaker Fathy el bably

\section{Chart (3)}

\section{Challenges that face companies to issue a sustainability report}

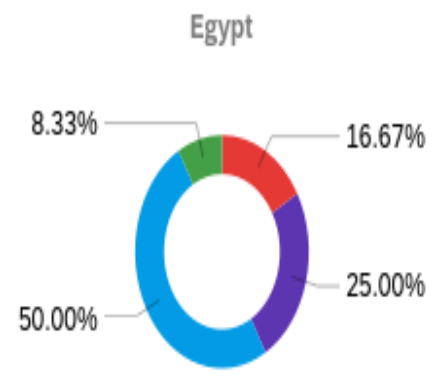

Table (4)

\begin{tabular}{|c|l|c|}
\hline$\#$ & Question & Total \\
\hline 1 & Incomplete data. & 8 \\
\hline 2 & Inaccuracy of data. & 12 \\
\hline 3 & Limited resources. & 24 \\
\hline 4 & Other reasons (Please specify) & 4 \\
\hline
\end{tabular}

العدد الأول الجزء الثاني •r.r. 
Evaluating the Impact of Current Sustainability Accounting Practices on ... Heba Shaker Fathy el bably

\subsection{Elements of Sustainability report:}

Chart (4) shows the responses of the practitioners who stated that they are issuing sustainability reports regarding the elements or the factors they report about in their sustainability report. The results reflect that companies that issue sustainability reports in Egypt do not follow the same guidelines and disclose diverse factors, as shown in table (5).

\section{Chart (4)}

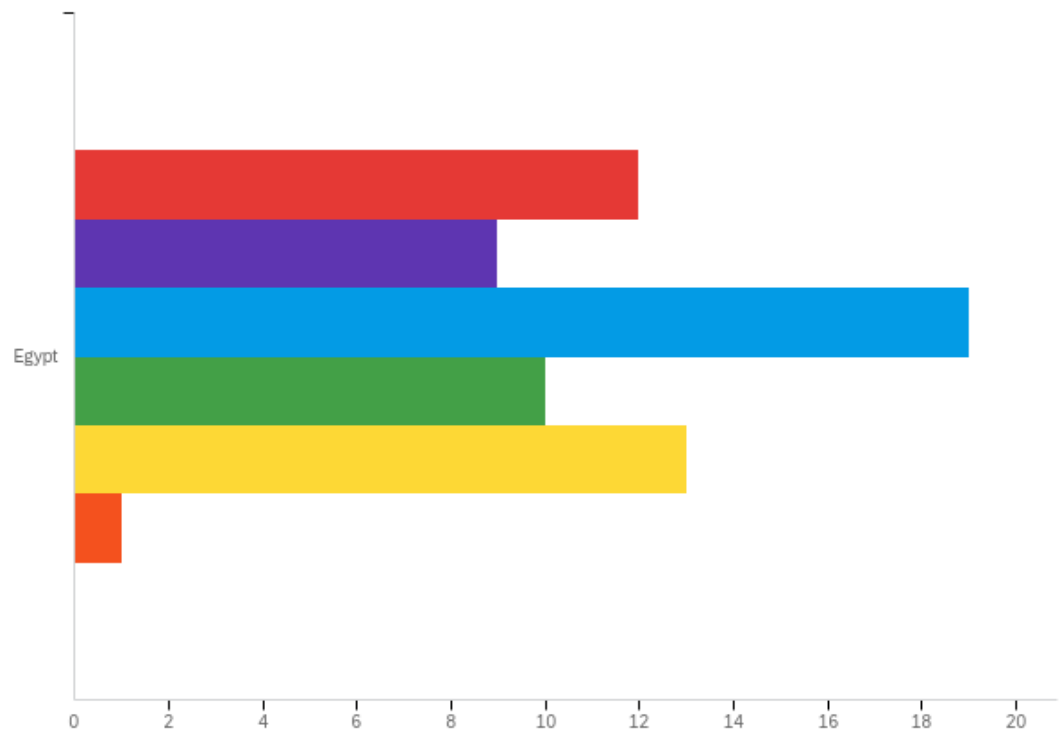

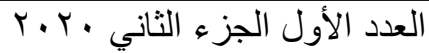

المجلد الحادي عشر - المر 
Evaluating the Impact of Current Sustainability Accounting Practices on ... Heba Shaker Fathy el bably

\begin{tabular}{|c|c|c|}
\hline \multicolumn{2}{c}{ Table (5) } \\
\hline$\#$ & Question & Total \\
\hline 1 & Environmental factors & 12 \\
\hline 2 & Social factors & 9 \\
\hline 3 & Economic factors & 19 \\
\hline 4 & Governance factors & 10 \\
\hline 5 & Business model and innovation factors & 13 \\
\hline
\end{tabular}

\section{Conclusion:}

As shown from the analysis of the current efforts of different professional organizations, and the results of the pilot study regarding the current practices, it is clear that many companies still ignore the significance of preparing sustainability reports. Additionally, Egyptian companies face many challenges that prevent them from accounting and reporting for their sustainability activities. Even though there are companies that issue sustainability reports, they are not following the same guidelines or even disclosing about the same factors. The absence of unified guidelines affects the ability to provide sustainability information that is comparable and consistent.

Finally, there is an essential need for further research to identify the causes for non-reporting, and the solutions of how to

المجلد الحادي عشر


Evaluating the Impact of Current Sustainability Accounting Practices on ... Heba Shaker Fathy el bably

harmonize research and practice in sustainability accounting and follow unified guidelines or standards to achieve transparency in accounting reporting.

\section{References:}

Adams, S., \& Simnett, R. (2011). Integrated Reporting: An Opportunity for Australias Not-for-Profit Sector. Australian Accounting Review, 21(3), 292301. doi: 10.1111/j.1835-2561.2011.00143.x

Amel-Zadeh, A., \& Serafeim, G. (2017). Why and How Investors Use ESG Information: Evidence from a Global Survey. SSRN Electronic Journal. doi: $10.2139 /$ ssrn. 2925310

Bradford, M., Earp, J. B., Showalter, D. S., \& Williams, P. F. (2017). Corporate Sustainability Reporting and Stakeholder Concerns: Is There a Disconnect? Accounting Horizons, 31(1), 83-102. doi: 10.2308/acch-51639

Cohen, J. R., Holder-Webb, L. L., Nath, L., \& Wood, D. (2012). Corporate Reporting of Nonfinancial Leading Indicators of Economic Performance and Sustainability. Accounting Horizons, 26(1), 65-90. doi: 10.2308/acch50073

Coram, P. J., Monroe, G. S., \& Woodliff, D. R. (2009). The Value of Assurance on Voluntary Nonfinancial Disclosure: An Experimental Evaluation. AUDITING: A Journal of Practice \& Theory, 28(1), 137-151. doi: 10.2308/aud.2009.28.1.137

Ernst Young, E. Y. (2014). Sustainability Reporting the time is now. EYGM limited. Preuzeto sa sajta dana, 31(08), 2016.

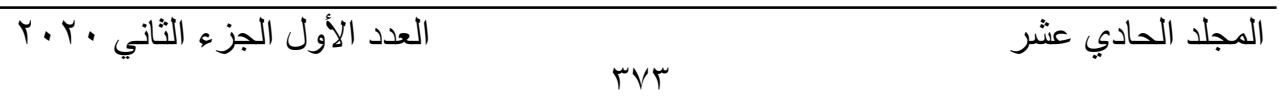


Evaluating the Impact of Current Sustainability Accounting Practices on ... Heba Shaker Fathy el bably

Fülöp, G., \& Hernádi, B. H. (2013). Sustainability accounting: A success factor in corporate sustainability strategy. Riga, University of Latvia.

GRI 101: FOUNDATION - Global Reporting Initiative. (2016). Retrieved from https://www.globalreporting.org/standards/media/1036/gri-101foundation-2016.pdf

Global Conference on Sustainability and Reporting ... (2013). Retrieved from https://www.globalreporting.org/resourcelibrary/2013-GRI-GlobalConference-in-Review.pdf

Guo, Y., \& Yang, D. C. (2014). Sustainability Accounting Reporting: A Survey on 30 U.S. Dow-Jones Companies. International Journal of Accounting and Taxation, 2(3). doi: 10.15640/ijat.v2n3a1

Hahn, R., \& Lülfs, R. (2013). Legitimizing Negative Aspects in GRIOriented Sustainability Reporting: A Qualitative Analysis of Corporate Disclosure Strategies. Journal of Business Ethics, 123(3), 401-420. doi: 10.1007/s 10551-013-1801-4

Hales, J., Matsumura, E. M., Moser, D. V., \& Payne, R. (2016). Becoming Sustainable: A Rational Decision Based on Sound Information and Effective Processes? Journal of Management Accounting Research, 28(2), 13-28. doi: 10.2308/jmar-51394

Haskin, D. L., \& Burke, M. M. (2016). Incorporating Sustainability Issues into The Financial Accounting Curriculum. American Journal of Business Education (AJBE), 9(2), 49-56. doi: 10.19030/ajbe.v9i2.9611

Hertgers, I. (2016). Integrated reporting. The implementation and development of integrated reporting at TenneT (Master dissertation).

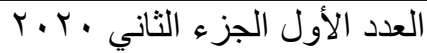

المجلد الحادي عشر 
Evaluating the Impact of Current Sustainability Accounting Practices on ... Heba Shaker Fathy el bably

International Integrated Reporting Council (IIRC). (2013). The International framework.

The KPMG Survey of Corporate Responsibility Reporting. (2013).

Retrieved from https://assets.kpmg/content/dam/kpmg/pdf/2015/08/kpmgsurvey-of-corporate-responsibility-reporting-2013.pdf

Munoz, E., Zhao, L., \& Yang, D. C. (2017). Issues in Sustainability Accounting Reporting. Accounting and Finance Research, 6(3), 64. doi: 10.5430/afr.v6n3p64

Nielsen, A. E., \& Thomsen, C. (2007). Reporting CSR - what and how to say it? Corporate Communications: An International Journal, 12(1), 25-40. doi: $10.1108 / 13563280710723732$

From PwC: Investors, Corporations, and ESG: Bridging the Gap. (2017). Retrieved from https://insights.ethisphere.com/from-pwc-investorscorporations-and-esg-bridging-the-gap/

SASB CONCEPTUAL FRAMEWORK. (2017). Retrieved from https://www.sasb.org/wp-content/uploads/2019/05/SASB-ConceptualFramework.pdf

Sridhar, K., \& Jones, G. (2012). The three fundamental criticisms of the Triple Bottom Line approach: An empirical study to link sustainability reports in companies based in the Asia-Pacific region and TBL shortcomings. Asian Journal of Business Ethics, 2(1), 91-111. doi: 10.1007/s13520-012-0019-3

المجلد الحادي عشر

